\title{
Climate change and disturbances will shape future temperate forests in the transition zone between Central and SE Europe
}

\author{
Lado Kutnar ${ }^{1 \oplus}$, Janez Kermavnar ${ }^{1}$, Anže Martin Pintar ${ }^{2}$
}

Kutnar L., Kermavnar J., Pintar A.M., 2021. Climate change and disturbances will shape future temperate forests in the transition zone between Central and SE Europe. Ann. For. Res. 64(2): 67-86.

Abstract It is expected that climate change as well as abiotic and anthropogenic disturbances will strongly influence temperate forests. Besides changes in the main climate variables, various disturbance factors may significantly worsen conditions for mesic Slovenian forests (SE Europe) dominated by European beech (Fagus sylvatica), Norway spruce (Picea abies) and European silver fir (Abies alba). In Slovenia, the climate has warmed in recent decades, with an average annual rate of increase of about $0.4^{\circ} \mathrm{C}$ per decade or even more than $0.5^{\circ} \mathrm{C}$ per decade in summer. In addition, disturbances have caused considerable damage to trees in the most extensive forest types in Slovenia, starting with a widespread ice storm in 2014 , followed by bark beetle outbreaks, windthrows and salvage logging interventions. After 2014, salvage logging increased from about one third to two thirds of the total annual felling. Over the last two decades, we have observed a decline in Norway spruce growing stock, with the highest rate of decrease in areas below $500 \mathrm{~m}$ a.s.1., and an increasing trend for European beech. Overall, the three dominant species (beech, spruce, silver fir), which together account for more than $70 \%$ of the total growing stock, have shown a declining trend over the last 20 years. The patterns observed are broadly consistent with earlier predictions developed for different climate change scenarios and with those reported in many other European countries. Adaptive forest management, which implements close-to-nature silviculture, has been traditionally practised in the region under study and has the potential to play an important role in reducing the risks associated with the impacts of climate change and disturbances in the future.

Keywords: climate warming; disturbance factors; ice storm; bark beetle outbreaks; spruce decline; salvage logging; tree species composition; temperate forest, Slovenia

Addresses: ${ }^{1}$ Department of Forest Ecology, Slovenian Forestry Institute, Ljubljana, Slovenia.| '2Department for Forest and Landscape Planning and Monitoring, Slovenian Forestry Institute, Ljubljana, Slovenia.

Corresponding Author: Lado Kutnar (lado.kutnar@gozdis.si).

Manuscript received December 18, 2020; revised September 06, 2021; accepted November 26, 2021. 


\section{Introduction}

Forests in Europe will have to adapt to changes in mean climate variables and to their increased variability, with a higher risk of extreme weather events, such as prolonged summer droughts, windstorms and floods (IPCC 2001, 2007, 2014, Lindner et al. 2010, Blennow et al. 2010).

In the twentieth century, climate change (hereafter CC) has obviously also increased the probability of large-scale, intensified disturbances such as windthrows and snow and ice breaking (Schelhaas et al. 2003), and CC is likely to increase forest disturbance hazard in the future (Thom et al. 2017). Disturbances and climate change are highly likely to interact, which can lead to synergistic or antagonistic ecological effects that are difficult to predict (Brook et al. 2008). Parallel to global warming, natural and anthropogenic disturbance regimes have changed significantly, so that these two driving forces of ecosystem dynamics can often mask or modify the effects of the other (Danneyrolles et al. 2019). Furthermore, the interactions between multiple abiotic and biotic stressors are not well understood, which further complicates the possible outcomes of direct and indirect $\mathrm{CC}$ effects (Chmura et al. 2011, Boisvert-Marsh et al. 2014).

Natural and human disturbances can be defined as relatively discrete events in time that disrupt the ecosystem and cause pronounced changes in resource availability or the physical environment (White \& Pickett 1985, Attiwill 1994), and they are a major driver of forest community dynamics (Goldblum \& Rigg 2010). Although highly variable in space and time, disturbances can have a lasting effect on forests and are increasingly affecting forest management (Seidl et al. 2011a, Grecs \& Kolšek 2017, Danneyrolles et al. 2019). Disturbances must therefore be taken into account when attempting to understand and predict the effects of $\mathrm{CC}$ on tree species distribution and forest formation (Bouchard et al. 2019), as they have been shown to enhance the response of tree communities to CC (Brice et al. 2019). Warmer and drier conditions are likely to favour fires, drought and insect disturbances in the future, while warmer and wetter conditions could increase wind and pathogen disturbances (Seidl et al. 2017).

The main components of a forest disturbance regime include disturbance type and frequency, severity, and spatial extent (Runkle 1985). All these descriptors are modulated by changing responses to current and future CC. An increasing frequency of large-scale disturbance events has been documented over the last decade, and this is expected to further increase in the future (Seidl et al. 2014). In Europe, damage caused by wind, insect outbreaks and forest fires has increased in forests over the course of the twentieth century. In addition, the synergistic interaction of various disturbance factors has been enhanced, e.g. drought increases the intensity of fires, and insect damage increases vulnerability to storms. These strong linkages are usually expressed as a cascade that occurs when abiotic disturbances are followed by insect outbreaks (Kausrud et al. 2012, de Groot et al. 2018). Widespread interactions between different abiotic and biotic agents are likely to increase the intensity and spatial extent of disturbances (Seidl et al. 2017), further strengthening the role of disturbances as critical drivers of forest ecosystem composition, structure and functioning (Bengtsson et al. 2000, Schelhaas et al. 2003, Seidl et al. 2011b, 2014, 2017, Thom \& Seidl 2016, Nagel et al. 2017).

Extreme weather events, such as extensive summer droughts, have a much greater effect on tree growth and survival than gradual changes in average climate conditions (Lindner et al. 2010). Warmer and drier conditions will lead to more frequent and extended droughts throughout Europe. Regions most vulnerable to increasing drought risk are the Mediterranean and some continental parts of Central and Eastern Europe, which could experience an increase in droughts and fire hazards by the end 
of the $21^{\text {st }}$ century (Polemio \& Casarano 2004, Goldammer et al. 2005, Good et al. 2006, Moriondo et al. 2006, IPCC 2007, 2014).

Future $\mathrm{CC}$ and associated changes in the disturbance regime are likely to be most pronounced in coniferous forests (Seidl et al. 2017), especially where conifers have been artificially introduced. Conifers are expected to decline due to water limitations (Lasch et al. 2002, Lexer et al. 2002, Martínez-Vilalta \& Pińol 2002) and higher temperatures (Pretzsch \& Dursky 2002), especially Norway spruce (Picea abies) and European silver fir (Abies $a l b a)$. These native conifers will probably be replaced by broadleaved tree species in Western and Central Europe (Maracchi et al. 2005, Koca et al. 2006, Kutnar \& Kobler 2011). However, drought may also negatively impact mesic deciduous forests (Broadmeadow et al. 2005, Kutnar \& Kobler 2011, 2014, Stojanović et al. 2013, 2014). Other abiotic threats to forests are likely to increase, although the expected impacts are regionally specific and will largely depend on the forest management system implemented (Kellomäki \& Leinonen 2005, Dobor et al. 2020).

For Slovenia, which is located in the transition area between three major geographic regions of SE Europe (Alps and Dinaric Mountains, Mediterranean Region, and the Pannonian Basin), various climate envelope models (Box et al. 1999, Pearson \& Dawson 2003, Hijmans \& Graham 2006) have been developed to predict the effects of $\mathrm{CC}$ on forests and tree species distribution (Kutnar \& Kobler 2011, 2013 , 2014). By the end of the $21^{\text {st }}$ century, mesic forests with predominant European beech (Fagus sylvatica) could be affected by changing environmental conditions (Thom et al. 2020). Under various climate warming scenarios, the proportion of dominant beech forests is likely to decrease, and the area of warmth-tolerant thermophilic forests and tree species will increase significantly (Kutnar \& Kobler 2011, 2014). In the coming decades, the distribution range and abundance of Norway spruce (Kutnar \& Kobler 2014) and European silver fir (Anić et al. 2009, Ficko et al. 2011) are likely to decrease. It is expected that the distribution areas of the currently dominant tree species will expand northwards and/or to higher altitudes and shrink at their marginal edges (Boisvert-Marsh et al. 2014, Thurm et al. 2018, Bouchard et al. 2019). All these expected changes are consistent with general observations related to global warming.

Besides the long-term shifts in tree species composition and forest distribution caused by changes in climate variables, CC-driven changes in forest disturbance patterns have to be considered. Natural and anthropogenic disturbance factors alone and together have caused considerable damage to Slovenian forests in recent years. Therefore, the objectives of this study are to assess i) changes in key climate variables over the last decades; ii) the effects of different disturbance factors on forests, a with special emphasis on a massive ice storm disturbance; and iii) the resulting changes in tree species composition in Slovenia.

\section{Materials and Methods}

\section{Study area}

Slovenian forests cover a total area of 1.2 million ha, which corresponds to $58 \%$ of the country's total area (ZGS 2005-2019). Due to its heterogeneous relief, its climate, and the legacy of former forest management, Slovenian forests consist of a diverse mosaic of forest types, ranging from lowland floodplain forests to widespread mesic mixed forests dominated by beech at medium altitudes and to mountainous coniferous forests at higher altitudes. In lowland areas that experience periodical flooding, forest stands occur in narrow strips along rivers and streams and are dominated mainly by willows (Salix sp.), alders (Alnus glutinosa, A. incana), ashes (Fraxinus excelsior, $F$. angustifolia) and common oak (Quercus robur). In the hilly areas above the 
floodplains, mixed forests of sessile oak (Quercus petraea) and hornbeam (Carpinus betulus) are the predominant forest type.

Most of the mountain areas are covered by forests of European beech (Fagus sylvatica) with mixtures of various broadleaved trees (e.g. Acer pseudoplatanus, Fraxinus excelsior, Ulmus glabra) and conifers (Abies alba, Picea abies). Dinaric forest of European beech and European silver fir (Abies alba) is one of the most extensive forest types in the country, covering more than $10 \%$ of the total forest area (Dakskobler 2008). In the Alpine region, various European beech forests mixed with Norway spruce (Picea abies), European silver fir, and European larch (Larix decidua) reach the timberline up to the belt of dwarf mountain pine (Pinus mugo).

Scots pine (Pinus sylvestris) forests can be found throughout the interior of the country on nutrient-poor soils. Austrian pine forests (Pinus nigra) grow on some extreme slopes of the continental part of the country with a warmer (micro)climate; this tree species was also planted over the greater part of southwestern Slovenia, in the Karst region. All over the country, forests and shrubby vegetation of various thermophilic deciduous species (e.g. Ostrya carpinifolia, Fraxinus ornus, Quercus pubescens, Q. cerris, Sorbus aria) extend mainly on limestone and dolomite rocks on warm south-facing slopes.

In its natural range, Norway spruce grows

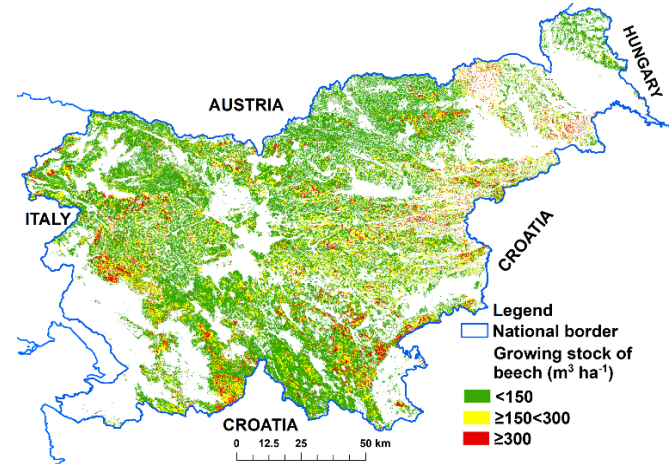

Figure 1 Spatial distribution of European beech (Fagus sylvatica) growing stock in Slovenia (Data source: ZGS 2018a). more abundantly only in the Alps in the north of the country and to a much lesser extent in cold valleys and karst depressions in the Dinaric region in the southern part of the country. However, in past centuries spruce was one of the most anthropogenically favoured tree species in Slovenia, as it was intensively introduced and planted in many regions because of its timber. In areas which lie outside its natural distribution, spruce is much more sensitive to extreme weather events, and widespread bark beetle infestation is more frequent, especially at lower altitudes (de Groot 2014, de Groot et al. 2016, Ogris \& Grecs 2016).

The dominant tree species in Slovenia in 2018 were Fagus sylvatica with 32.4\% (Fig. 1), Picea abies with $30.6 \%$ (Fig. 2) and Abies alba with $7.4 \%$ of the total growing stock (ZGS 2005-2019). The management of Slovenian forests is based on sustainable, close-to-nature and multi-purpose principles. The relatively low intensity and un-even aged silviculture is mostly oriented towards near-natural tree species composition (Diaci 2006).

\section{Analysis of meteorological and climatic data}

We analysed meteorological data for Slovenia from the data archive of the Slovenian Environment Agency (hereafter ARSO) (ARSO 2019). We analysed the mean annual temperature $\left({ }^{\circ} \mathrm{C}\right)$ and annual precipitation $(\mathrm{mm})$, number of days with snow cover

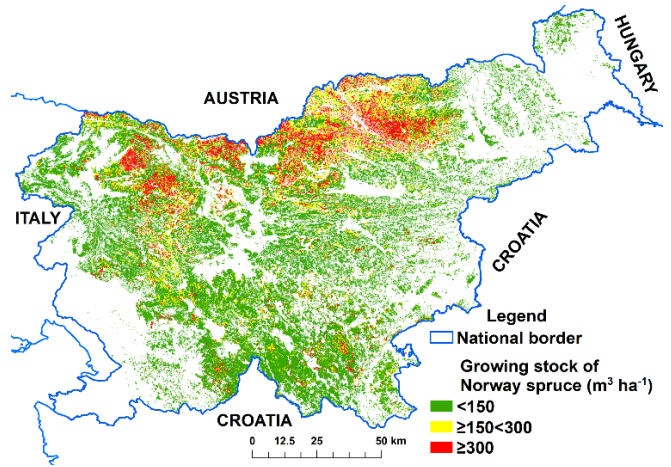

Figure 2 Spatial distribution of Norway spruce (Picea abies) growing stock in Slovenia (Data source: ZGS 2018a). 
and maximum snow cover $(\mathrm{cm})$, and their linear trends for the last 60 years (1959-2018). Continuous meteorological measurements for the period 1959-2018 were available for only five meteorological stations, namely Ljubljana (299 m a.s.1.), Brnik (384 m), Šmartno (452 m), Rateče (864 m) and Kredarica (2513 m) (ARSO 2019).

For the period from 2000 to 2018, 25 ARSO meteorological stations throughout Slovenia provided data for the following climate variables: mean temperature $\left(\mathrm{T}_{\text {avg }}\right)$, mean daily temperature maximums $\left(\mathrm{T}_{\max }\right)$, relative humidity $(\mathrm{RH})$ and amount of precipitation (P) (ARSO 2019). The distribution of meteorological stations among altitudinal belts was as follows: $<500 \mathrm{~m}$ a.s.1.: 16 stations; $>500 \mathrm{~m}$ and <1000 m: 5 stations; $>1000 \mathrm{~m}: 4$ stations. We compared the changes in climate variables and their linear trends for annual data (12-month average) and separately for the summer period (average for June, July, August) (ARSO 2019). Five meteorological stations were used for evaluation of climate variables in a 60-year period (1959-2018), and a subset of the series of 25 stations was used for analysis of a 19-year period (2000-2018). We used all available meteorological stations in Slovenia with complete data series and continuous measurement for both periods.

\section{Analysis of disturbance effects for Slovenian forests}

The forest damage caused by various abiotic and biotic disturbances was estimated at the compartment level (ZGS 2015, 2005-2019). The compartment is the smallest spatial organisational unit in forest management planning in Slovenia, with an average size of 22 ha (ZGS 2018b). The negative impacts of various disturbances in Slovenian forests were assessed on the basis of the amount of salvage logging in the forests over a 15-year period (2004-2018). In this analysis six different disturbance factors were distinguished: i) insect infestation, ii) diseases and fungal pathogens, iii) windthrows, iv) snow-breakage, v) ice storms, and vi) other factors, e.g. logging of decaying and physiologically weakened trees, tree damage caused by regular forest operations, local emissions, wildlife, avalanches and landslides. We compared the annual volume of salvaged timber from damaged and removed coniferous and broadleaved tree species. All data were compiled from the annual reports of the Slovenia Forest Service (ZGS 2005-2019).

Using ArcMap software (ESRI 2018), we analysed forest damage caused by a large-scale ice storm event in 2014, and the decrease in the growing stock of Norway spruce based on data from 2010 and 2018. The effects of the massive ice storm disturbance on forest trees and stands were analysed by distinguishing between severely damaged forests (more than $10 \%$ of all trees were damaged) and damaged forests (less than $10 \%$ and more than $0 \%$ of all trees were damaged). The intensity of the damage was compared at the level of forest types.

For the analysis of changes in Slovenian forests, extensive data on more than 335,000 forest stands and more than 53,700 forest compartments from the Slovenia Forest Service were used (ZGS 2010a, 2010b, 2018a, 2018b). The forest stand is a relatively homogeneous part of the forest in terms of tree species composition, developmental stage or age of the predominant trees, etc., and corresponds to the spatial unit that is important for forest inventory, planning, and management unit consisting of several different stands. From the forest stand data, we calculated the average growing stock $\left(\mathrm{m}^{3} \mathrm{ha}^{-1}\right)$ of Norway spruce for each compartment. The analyses included compartments where spruce growing stock in the year 2010 was equal to or higher than 20 $\mathrm{m}^{3} \mathrm{ha}^{-1}$. We prepared a spatial map showing the decline of the spruce growing stock in each compartment. We distinguished between three classes of decline: i) $<25 \%$, ii) $\geq 25 \%$ $<50 \%$, and iii) $\geq 50 \%$. We also calculated the average altitude of each compartment. Of all compartments, $40 \%$ were located in the lowest altitudinal belt $(<500 \mathrm{~m}), 45 \%$ in the middle 
altitudinal belt $(\geq 500 \mathrm{~m}<1000 \mathrm{~m})$ and $15 \%$ in the highest altitudinal belt $(\geq 1000 \mathrm{~m})$.

\section{Statistical analyses}

Linear models were used to test trends in climate variables (temperature, precipitation) during the entire period from 1959 to 2018 . Separate models were fitted for the first 30-year period (1959-1988) and second 30-year period (1989-2018). These models indicate whether the slope of the regression line is significantly $(p<0.05)$ different from zero. The coefficient of determination $\left(\mathrm{R}^{2}\right)$ was used as an overall measure of goodness-of-fit. Linear models were also constructed for $\mathrm{T}_{\mathrm{avg}}, \mathrm{T}_{\max }, \mathrm{RH}$ and $\mathrm{P}$ for the period from 2000 to 2018 .

For salvage logging data, differences in percentages of damaged trees $(\%$ of the total growing stock per year) were tested between three 5-year periods (2004-2008, 20092013, 2014-2018) using a non-parametric Kruskal-Wallis rank sum test with Dunn's post-hoc test and Bonferroni correction for multiple comparisons. For the entire period (2004-2018), a linear model was applied to each disturbance factor (insects, diseases and fungi, windthrow, snow, ice storm) and tree species group (conifers, broadleaves, all species). These models indicate whether the slope of the regression line is significantly ( $p$ $<0.05$ ) different from zero. The coefficient of determination $\left(\mathrm{R}^{2}\right)$ was used as an overall measure of goodness-of-fit.

For the period 1999-2018, linear models were fitted to examine changes in the share of the main tree species (spruce, beech, fir) and species groups (conifers, deciduous, dominant tree species together). A separate model was used for the first 10-year period (1999-2008) and the second 10-year period (2009-2018). The models indicate whether the slope of the regression line is significantly $(p<0.05)$ different from zero. The coefficient of determination $\left(\mathrm{R}^{2}\right)$ was used as an overall measure of goodness-of-fit.

For each compartment, relative change in the spruce growing stock (GS, $\mathrm{m}^{3} \mathrm{ha}^{-1}$ ) from 2010 to 2018 was calculated with the formula:

$$
\left(\left(\mathrm{GS}_{2018}-\mathrm{GS}_{2010}\right) / \mathrm{GS}_{2010}\right) \times 100 .
$$

Compartments with negative relative change (i.e. decrease) in spruce growing stock were considered for further analysis. Differences in the relative decrease in spruce among three altitudinal belts were tested with a one-way Analysis of Variance (ANOVA).

All described statistical analyses were conducted with the $\mathrm{R}$ software version 3.5.2 ( $\mathrm{R}$ Core Team 2018). The agricolae package (de Mendiburu 2020) was used for statistical procedures. In all statistical tests, the significance level was set at $\alpha=0.05$.

\section{Results}

\section{Changes in the main climate variables in Slovenia in the last decades}

In Slovenia, several climate variables have changed significantly over the last six decades (Fig. 3, Fig. 1S, 2S, and 3S). On average, the annual temperature calculated for five meteorological stations has increased over the last 60 years (1959-2018). The temperature increase ranged from $0.31^{\circ} \mathrm{C}$ per decade (Kredarica station at $2513 \mathrm{~m}$ ) to $0.46^{\circ} \mathrm{C}$ per decade (Ljubljana station at $299 \mathrm{~m}$ ), and the average rate of temperature increase was $0.38^{\circ} \mathrm{C}$ per decade $\left(\mathrm{p}<0.001, \mathrm{R}^{2}=58.1 \%\right)$. On average, the temperature increased non-significantly $(\mathrm{p}>$ $0.05)$ by $0.02^{\circ} \mathrm{C}$ per decade in the period 1959 1988 , and significantly $\left(\mathrm{p}<0.001, \mathrm{R}^{2}=31.9 \%\right)$ by $0.41^{\circ} \mathrm{C}$ per decade in the period $1989-2018$ (Fig. 3). Average annual precipitation (mm) over the last 60 years (1959-2018) decreased non-significantly $(\mathrm{p}>0.05)$ by $0.4 \%$ per decade, but if only the period 1989-2018 is considered, it actually increased at an average rate of $2.2 \%$ per decade (Fig. 1S). In contrast to changes in average annual temperatures, trends in annual precipitation amount were not statistically significant. On average, the number of days with snow cover decreased (5.2 days per decade; 

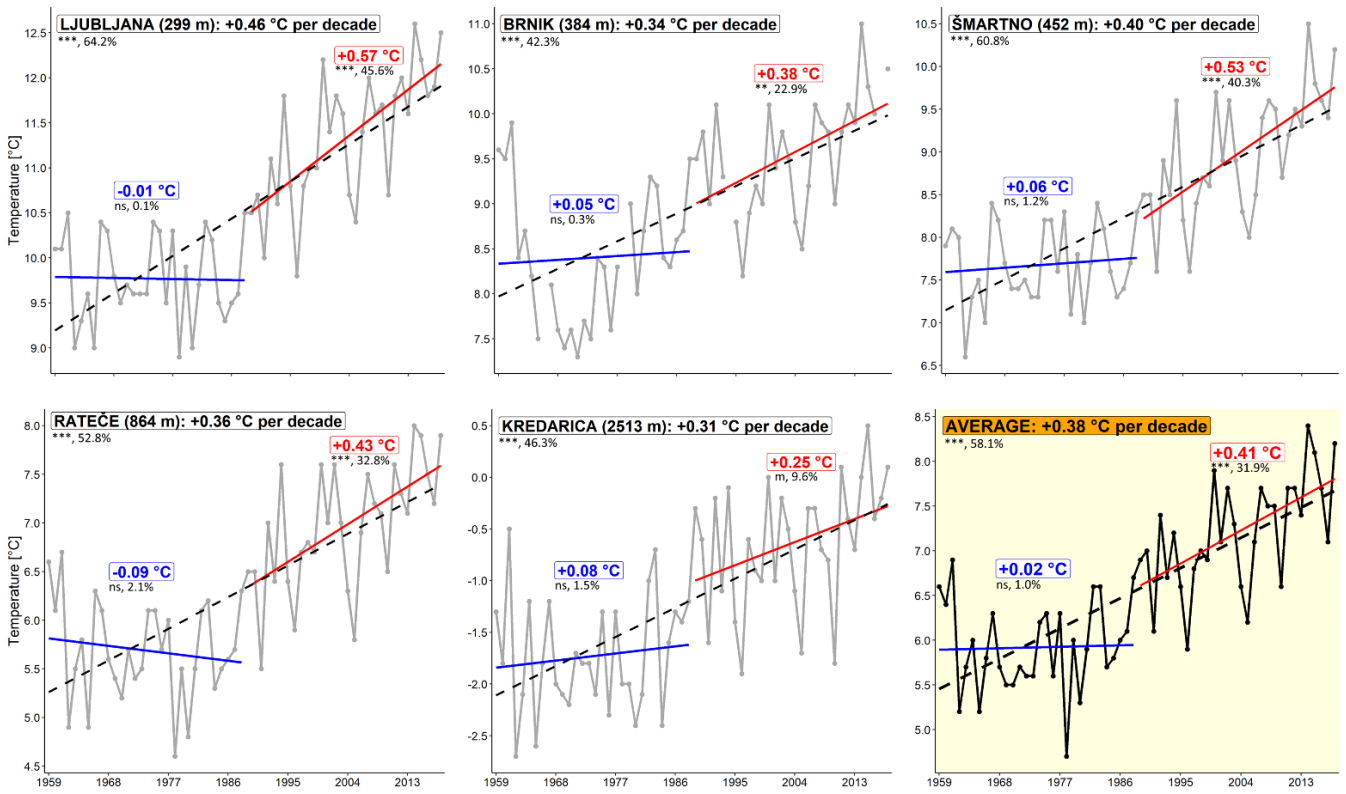

Figure 3 Mean annual temperature $\left({ }^{\circ} \mathrm{C}\right)$ for five Slovenian meteorological stations and their average (bottom-right panel) over the last 60 years and (1959-2018) (Data source: ARSO 2019).

Fig. 2S) and maximum snow cover decreased (2.7 $\mathrm{cm}$ per decade; Fig. $3 \mathrm{~S})$ in the period under study, except for the Kredarica station, which exhibited a slightly increasing trend for maximum snow cover.

We also observed changes in meteorological variables for the period from 2000 to 2018 (Fig. 4). For the set of 25 meteorological stations in Slovenia, the mean annual temperature ranged between $-0.5^{\circ} \mathrm{C}$ (Kredarica, $2513 \mathrm{~m}$ a.s.1.) and $14.0^{\circ} \mathrm{C}$ (Portorož, $2 \mathrm{~m}$ ) and the mean annual precipitation between $768.9 \mathrm{~mm}$ (Lendava, $190 \mathrm{~m}$ ) and $2859.3 \mathrm{~mm}$ (Vogel, $1535 \mathrm{~m}$ ). On average, the values of all climate variables, i.e. $\mathrm{T}_{\text {avg }}, \mathrm{T}_{\text {max }}, \mathrm{RH}$ and $\mathrm{P}$, have shown an increasing trend over the last two decades. Results from the linear models indicate that all trends in these variables were statistically non-significant. Mean annual temperature ( $\left.\mathrm{T}_{\text {avg }}\right)$ exhibited the most pronounced increasing trend (marginally significant, $\mathrm{p}<0.1$ ). $\mathrm{T}_{\text {avg }}$ (Fig. $4 \mathrm{a}$ ) and $\mathrm{T}_{\max }$ (Fig. 4b), calculated from 12 months of data, increased by $0.44^{\circ} \mathrm{C}$ per decade. The increase in mean and maximum temperature during the summer period (average for June, July, August) was more than $0.5^{\circ} \mathrm{C}$ per decade (Fig. $4 \mathrm{a}, 4 \mathrm{~b}$ ). Relative humidity increased by $3.0 \%$ (annual average) and by $2.6 \%$ (summer average) per decade. On average, $\mathrm{P}$ increased by $7.9 \%$ (annual average) and by $1.4 \%$ (summer average) per decade (Fig. 4d).

\section{Effects of large-scale disturbances on forest stands}

A variety of disturbance factors, such as windstorms, ice storms and insect outbreaks, caused damage to Slovenia's forests (Fig. 5). After the ice storm, the share of salvage logging in the total annual felling increased from about one third to two thirds. In the period 2004-2013, the amount of salvage logging was between 0.7 and 1.3 million $\mathrm{m}^{3}$ of damaged trees per year. In the period 2014-2018, it increased to a level between 2.6 and 4.2 million $\mathrm{m}^{3}$ per year. In 2014, more than three million $\mathrm{m}^{3}$ of wood damaged by the ice was logged. During the ice storm event, trees were either uprooted or snapped, or their crowns were slightly to severely damaged. The amount of salvage 


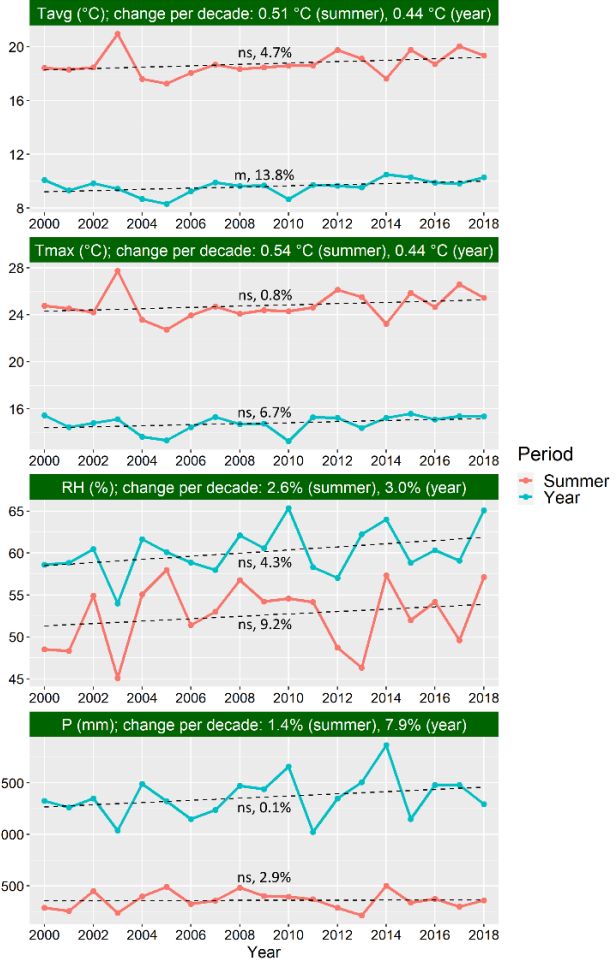

Figure 4 Mean temperature $\left(\mathrm{T}_{\text {avg }}\right)$, mean daily temperature maximums $\left(\mathrm{T}_{\max }\right)$, relative humidity $(\mathrm{RH})$, and precipitation $(\mathrm{P})$ for 25 meteorological stations (ARSO) in Slovenia, for the period 2000 to 2018 (Data source: ARSO 2019). logging due to bark beetle outbreaks increased significantly, as almost 6 million $\mathrm{m}^{3}$ wood was damaged in the period 2014-2018 (ZGS 2005-2019). Other abiotic and biotic factors, such as windthrows, tree diseases and heavy snow, caused additional damage and increased salvage logging in the years after 2014 (Fig. $5)$. Linear models revealed that in the period 2014-2018, the share of trees damaged by insects increased marginally significantly $(\mathrm{p}<$ $0.1, \mathrm{R}^{2}=20.7 \%$ ). The share of trees damaged by other disturbance factors also increased during this period (except for damage caused by diseases and fungi), but these trends were not significant $(\mathrm{p}>0.05)$. Overall, the share of damaged conifers $\left(\mathrm{p}<0.01, \mathrm{R}^{2}=46.4 \%\right)$, deciduous trees $\left(\mathrm{p}<0.05, \mathrm{R}^{2}=30.1 \%\right)$ and all tree species $\left(p<0.01, R^{2}=47.6 \%\right)$ increased in the studied period.

In the last 15 years, insects represented the most influential disturbance factor in Slovenian forests, with bark beetles causing the highest tree mortality (Table 1). Other significant disturbing factors were ice damage and windthrows. On average, all disturbances caused damage amounting to 1.9 million $\mathrm{m}^{3}$ per year, which corresponds to $0.56 \%$ of the total growing stock. We found that the share of damaged trees by insects was significantly higher in the 5-year period 2014-2018 compared to the period 2009-2013 (Table 1).

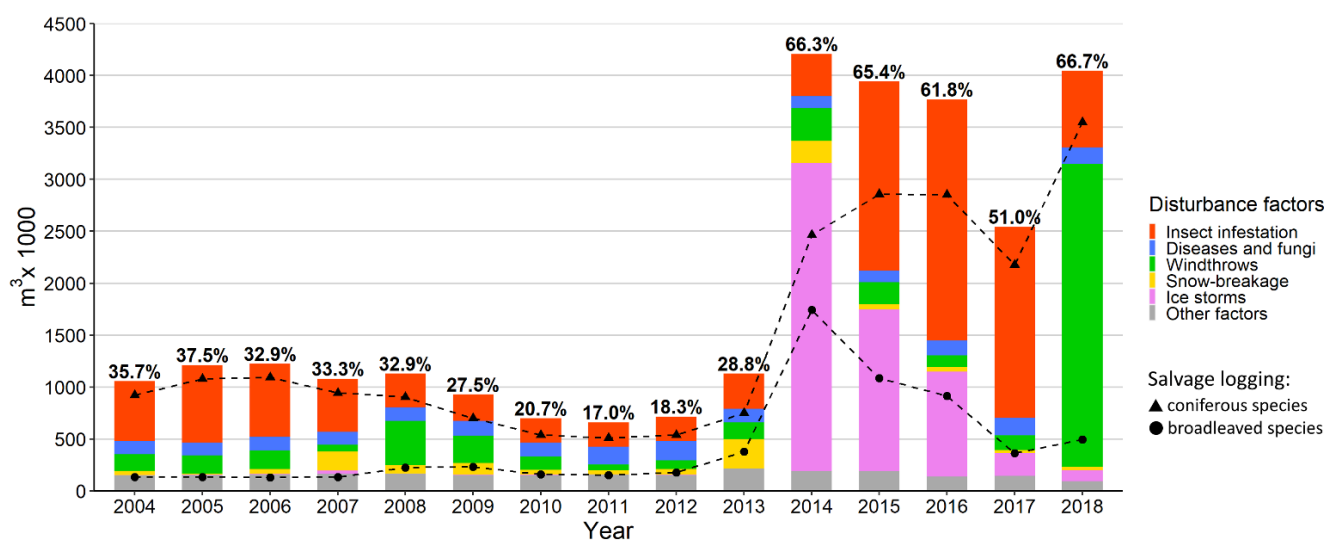

Figure 5 The volume of salvage logging $\left(\mathrm{m}^{3} \times 1,000\right)$ in Slovenian forests over the last 15 years $(2004$ 2018). The percentages above each bar indicate the proportion of salvage logging in the total annual felling (Data source: ZGS 2005-2019). 
Table 1 Share of damaged trees by main disturbance factors (in $\%$ of the total growing stock per year).

\begin{tabular}{|c|c|c|c|c|c|c|c|c|c|c|c|c|c|c|c|c|}
\hline \multirow[b]{2}{*}{ period } & \multicolumn{2}{|c|}{ insects } & \multicolumn{2}{|c|}{$\begin{array}{l}\text { diseases and } \\
\text { fungi }\end{array}$} & & \multicolumn{2}{|c|}{$\begin{array}{c}\text { snow- } \\
\text { breakage }\end{array}$} & \multicolumn{2}{|c|}{ ice storm } & \multicolumn{2}{|c|}{ conifers } & \multicolumn{2}{|c|}{ broadleaves } & \multicolumn{2}{|c|}{ all species } \\
\hline & aver. & $p=0.008$ & aver. & $\mathrm{p}=0.232$ & aver. & $\mathrm{p}=0.386$ & aver. & $\mathrm{p}=0.763$ & aver. & $\mathrm{p}=0.028$ & aver. & $\mathrm{p}<0.001$ & aver. & $p=0.006$ & aver. & $\mathrm{p}<0.001$ \\
\hline 2004-2008 & 0.19 & $a b$ & 0.04 & $\mathrm{a}$ & 0.07 & $\mathrm{a}$ & 0.02 & a & 0 & $\mathrm{a}$ & 0.32 & a & 0.05 & a & 0.37 & $\mathrm{a}$ \\
\hline 2009-2013 & 0.08 & a & 0.05 & a & 0.04 & $\mathrm{a}$ & 0.03 & $\mathrm{a}$ & 0 & a & 0.18 & $\mathrm{a}$ & 0.07 & a & 0.25 & $\mathrm{a}$ \\
\hline 2014-2018 & 0.41 & b & 0.04 & a & 0.21 & $\mathrm{a}$ & 0.02 & a & 0.34 & $\mathrm{~b}$ & 0.79 & $b$ & 0.26 & $b$ & 1.06 & $\mathrm{~b}$ \\
\hline 2004-2018 & 0.22 & I & 0.04 & 1 & 0.11 & I & 0.03 & 1 & 0.11 & 1 & 0.43 & 1 & 0.13 & 1 & 0.56 & 1 \\
\hline
\end{tabular}

A significant difference was also detected for ice damage. The share of damaged trees by other disturbance factors did not differ significantly between the three 5 -year periods. The share of damaged conifers, deciduous trees and all tree species together was significantly higher in the last 5-year period (2014-2018) compared to the period 2009-2013 and 2004-2008. Overall, forest disturbances damaged a significantly higher proportion of trees in the last 5-year period (2014-2018; $1.06 \%$ of total growing stock per year) compared to the first 5-year period (2004-2008; 0.37\%). The damaging effects for all main disturbance factors increased from the first to the last period, from $0.19 \%$ to $0.41 \%$ of the growing stock per year for insects, from $0.07 \%$ to $0.21 \%$ for wind, and from $0.00 \%$ to $0.34 \%$ for ice (Table 1 ).

\section{Effects of massive ice storm disturbance on forests}

In the period between January $30^{\text {th }}$ and February $10^{\text {th }}, 2014$, an extreme ice storm caused extensive damage to Slovenian forests. In terms of its spatial extent and the total amount of damaged wood, this event was the most catastrophic natural disturbance ever recorded in Slovenia. More than half of Slovenia's forests $(609,413$ ha) were damaged during the ice storm event (ZGS 2015). Within these disturbed areas, the proportion of damaged trees varied considerably, ranging from $0.1 \%$ to $85.0 \%$. In forest areas with a total area of 105,856 ha, more than $10 \%$ of the trees were either uprooted or snapped, or their crowns were damaged (Fig. 6), and forests with more than $50 \%$ damaged trees covered an area of 6,749 ha.

The ice disturbance and resulting tree damage occurred in a variety of forests on different bedrocks, mostly in the submontane to montane belt. (Fig. 6). In terms of the extent of area damaged by the ice, Dinaric fir-beech forests were the worst affected forest type. More than $60 \%$ of Dinaric fir-beech forests (146,608 ha in total) were damaged, and $13.5 \%$ of these forests were severely damaged (more than 10\% of all trees damaged) (Fig. 6). Acidophilic beech forests (431,702 ha in total) were among the significantly disturbed forests. In total, $41.0 \%$ of these forests were damaged and $4.6 \%$ were severely damaged. Almost $60 \%$ of submontane beech forests $(60,326$ ha in total) were damaged, and $10.9 \%$ of the total area was severely damaged (Fig. 6).

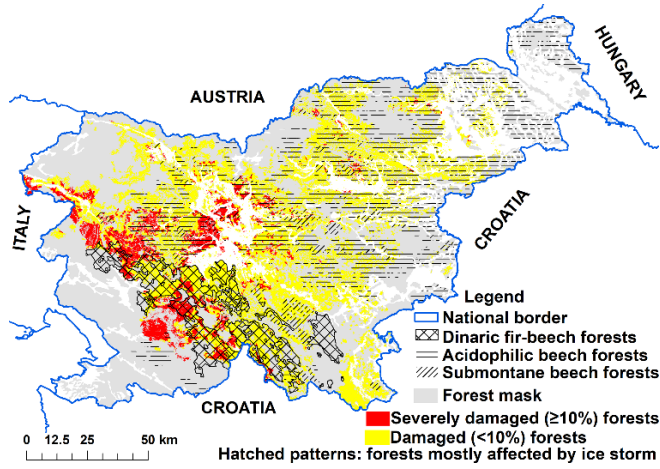

Figure 6 Slovenian forests mostly affected by the large-scale ice storm event in 2014 (Data source: ZGS 2015, Čarni et al. 2002).

\section{Changes in tree species composition}

The proportion of Norway spruce (Fig. 7a) in the growing stock decreased significantly over the period 1999-2018 $\left(\mathrm{p}<0.001, \mathrm{R}^{2}=94.6 \%\right)$. In 1999, Norway spruce was the most common tree species in the growing stock with $32.5 \%$. 

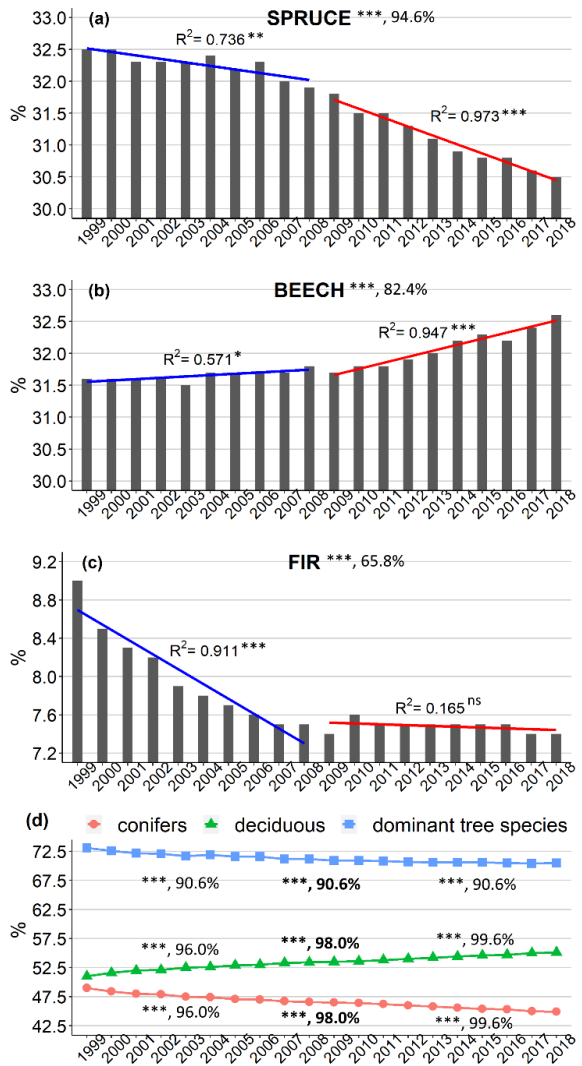

Figure 7 Temporal changes in the proportion of three dominant tree species (a to c) and cumulative for the groups of different tree species (d) in the total growing stock of Slovenian forests in the last 20 years (1999-2018) (Data source: ZGS 20052019).

Twenty years later, its share decreased to $30.5 \%$. This decline was particularly evident in the last 10 years (2009-2018). In contrast to spruce, the proportion of European beech (Fig. $7 b)$ increased significantly $\left(\mathrm{p}<0.001, \mathrm{R}^{2}=\right.$ $82.4 \%$ ), with the rate of increase accelerating in the last 10 years. The growing stock of European beech remained at a similar level for almost 15 years (about 31.7\%) and then gradually increased to $32.6 \%$ in 2018 . The share of silver fir significantly $\left(\mathrm{p}<0.001, \mathrm{R}^{2}\right.$ $=65.8 \%$ ) decreased by 1.6 percentage points between 1999 and 2018. However, its decrease was significant only in the first half of the period under study (1999-2008), while the decline in the second half was not statistically significant (Fig. 7c).

In line with the changes described for the main tree species, the ratio between coniferous and broadleaves in the growing stock also changed significantly over the period 19992018. The share of coniferous species (Norway spruce, European silver fir and other) significantly decreased $\left(\mathrm{p}<0.001, \mathrm{R}^{2}=98.0 \%\right)$ from over $49 \%$ to about $45 \%$, while the share of broadleaved species (European beech and other broadleaves) significantly increased by about 4 percentage points (Fig. $7 d$ ). The linear models revealed a significant declining trend $\left(\mathrm{p}<0.001, \mathrm{R}^{2}=90.6 \%\right)$ for the proportion of the three dominant tree species, i.e. cumulative $\%$ for beech, spruce and fir (Fig. 7d).

In the period from 2010 to 2018 , Norway spruce growing stock decreased in 17,570 compartments with a total area of 611,148 ha. The strongest decline in Norway spruce growing stock $(\geq 50 \%)$ took place in 108,000 ha of the examined forests (Fig. 8, Table 2). Of these, 52\% were located in the lowest $(<500 \mathrm{~m}$ a.s.1.), $40 \%$ in the middle $(\geq 500 \mathrm{~m}<1000 \mathrm{~m}$ ) and only $8 \%$ in the highest altitudinal belt $(\geq 1000 \mathrm{~m})$.

There was an intermediate decline in Norway spruce growing stock $(\geq 25 \%<50 \%)$ on 122,100 ha. Half of these forest areas were located in the lowest, $39 \%$ in the middle and $11 \%$ in the

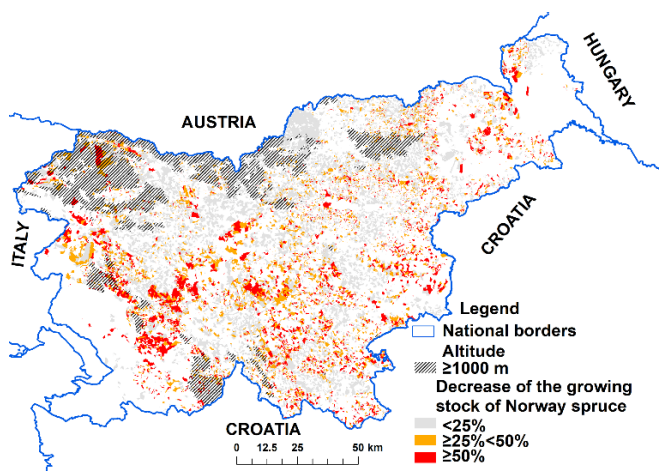

Figure 8 Decrease in the spruce growing stock from 2010 until 2018 (Data source: ZGS 2010a, 2010b, 2018a, 2018b, EUROSTAT 2018). 
highest altitudinal belt. The lowest level of spruce decline (less than 25\%) mainly occurred in compartments located in the middle altitudinal belt (Fig. 8, Table 2).

The highest proportion of forests with higher rates of spruce decline was observed in the lowest belt $(<500$ m) (Fig. 9). Relative spruce decline at lower altitudes was significantly higher compared to the other two belts (Fig. 10).
Table 2 Decline classes in the growing stock (GS) of Norway spruce, according to data from 2010 and 2018 (Data source: ZGS 2010a, 2010b, 2018a, 2018b, EUROSTAT 2018).

\begin{tabular}{lccc}
\hline Decline in GS (\%) & $\begin{array}{c}\text { Altitudinal } \\
\text { belt (m a.s.l.) }\end{array}$ & Area (x 1000 ha) & $\begin{array}{c}\text { Proportion } \\
(\%)\end{array}$ \\
\hline$\geq 50$ & $<500$ & 56.5 & 52 \\
$\geq 50$ & $\geq 500<1000$ & 43.3 & 40 \\
$\geq 50$ & $\geq 1000$ & 8.2 & 8 \\
\hline Total $(\geq 50)$ & $<500$ & 108.0 & 100 \\
\hline$\geq 25<50$ & $\geq 500<1000$ & 47.0 & 50 \\
$\geq 25<50$ & $\geq 1000$ & 13.4 & 39 \\
$\geq 25<50$ & & 122.1 & 11 \\
\hline Total $(\geq 25<50)$ & $<500$ & 151.8 & 100 \\
\hline 25 & $\geq 500<1000$ & 175.5 & 40 \\
$<25$ & $\geq 1000$ & 53.8 & 14 \\
$<25$ & & 381.1 & 100 \\
\hline Total $(<25)$ & & & \\
\hline
\end{tabular}

\section{Discussion}

\section{Long- and short-term variation in crucial climate variables}

In the age of $\mathrm{CC}$, forest ecosystems worldwide are under enormous pressure. Changes in climatic conditions and an increase in the frequency and severity of forest disturbances and other stress factors (drought and heat stress) could fundamentally alter the composition, structure and biogeography of forests in many regions. A continuation of the 60 -year trends analysed for Slovenia suggests an increase in mean temperature of $3.0^{\circ} \mathrm{C}$ and a decrease in precipitation of about $3 \%$ by the end of this century. However, the current 20year trend assumes an even stronger increase in mean annual temperature in this region, and maximum summer temperatures could be $4.3^{\circ} \mathrm{C}$ higher by the end of the century. In contrast to a steady rise in temperature, the changes in precipitation proved to be more variable and therefore less predictable. The 60-year trend indicates a decreasing amount of precipitation. In recent decades, however, the amount of precipitation has actually increased. Higher precipitation and relative humidity could be related to the occurrence of extreme weather events, although high spatial variability in precipitation (due to the complex terrain) could most likely offset the general

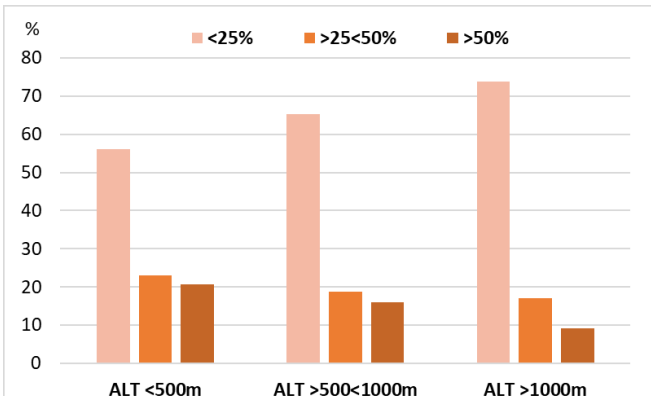

Figure 9 Relative proportion of the decline classes of spruce growing stock in three altitudinal belts (Data source: ZGS 2010a, 2010b, 2018a, 2018b, EUROSTAT 2018).

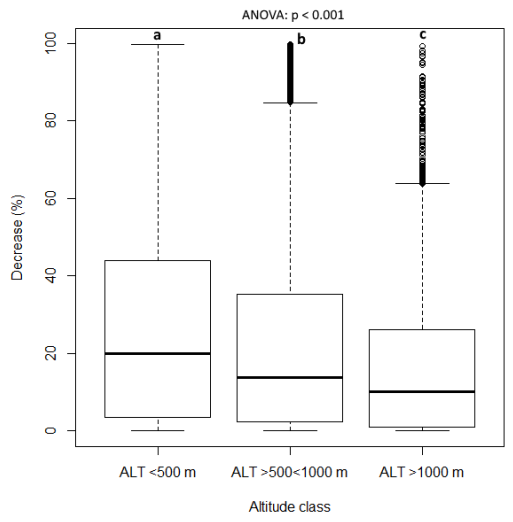

Figure 10 Relative decrease (\%) in spruce growing stock for different altitudinal belts (Data source: ZGS 2010a, 2010b, 2018a, 2018b, EUROSTAT 2018). 
trends locally, which would make the future responses of forests even more uncertain.

We can state with greater certainty that rising temperatures could have an adverse effect on tree growth and survival. Extreme events such as extreme droughts and heat waves are important drivers of tree mortality and are expected to increase in frequency and intensity with CC. When high temperatures are combined with low soil water availability, the effects of droughts can be amplified by increased evapotranspiration, and trees can die rapidly (Taccoen et al. 2019). The warming of the future climate with higher average temperatures and even more extreme summer temperatures will also lead to further disturbance events. Overall, disturbance regimes have proved to be very sensitive to both climate means and extremes (Thom et al. 2013).

\section{Changes in tree species composition}

It has been shown that forest disturbances are one of the most important factors determining the rate of shift in tree species distribution with CC (Vanderwel \& Purves 2014, Seidl et al. 2017). Our study showed that Slovenian forests have undergone profound changes in their structure and composition in recent years. Both natural disturbances and salvage logging have caused considerable damage to overstory trees and also damage to forest soils. Disturbances have resulted in a high proportion of degraded forests with many larger canopy gaps and openings, where younger developmental phases occur. Various disturbance factors have changed the tree species composition towards an increased proportion of broadleaved species. In total, the proportion of the three dominant tree species (beech, spruce, silver fir) has decreased in Slovenian forests during the last two decades.

In the last 15 years, insect and wind damage has affected on average $0.22 \%$ and $0.11 \%$ of the growing stock per year, respectively, which is comparable to Austrian forests (Thom et al. 2013). However, most of the damage has occurred in recent years. Largescale disturbances, beginning with the severe ice storm in 2014 and subsequent bark beetle outbreaks and windthrows, caused severe damage, especially to forest types with a higher proportion of Norway spruce introduced by humans. This tree species has suffered the greatest decline; its share has decreased by 1.3 percentage points over the last ten years. If this current downward trend in spruce continues, its share in the total growing stock will only be about $20 \%$ by the end of the century. However, the constantly increasing temperature and climate extremes with $\mathrm{CC}$ induced disturbances could further accelerate the decline of spruce in the coming decades. In contrast, European beech has increased its share of the total growing stock, which is mainly due to the decline of Norway spruce and silver fir. However, for Slovenia (Kutnar \& Kobler 2011, 2014) and Europe (Hanewinkel et al. 2013), it is predicted that even beech will start to lose its share in the second half of the $21^{\text {st }}$ century.

The expected decline of spruce and the current changes in tree species composition indicate changes in Slovenian forests that are consistent with CC predictions for Slovenian forests that were made $\sim 10$ years ago (Kutnar \& Kobler 2011, 2014). The majority changes in the observed forest stands and tree species have been in accordance with predictions. Furthermore, the results of the present study suggest that the magnitude of these changes has been amplified by increasing disturbance effects.

The significant decline in spruce is mainly due to the high spruce damage during the ice storm in 2014 (Nagel et al. 2016) and the particularly widespread bark beetle outbreaks in the following years. Crown damage and negative influences on the root system weakened their ability to cope with abiotic and biotic stressors. In addition, the predicted increase in summer temperatures and, as a consequence, prolonged droughts increased their vulnerability and contributed to higher tree mortality. It is expected that rising temperatures will accelerate the development 
cycle of the spruce bark beetle (Ips typographus L.) and increase its reproductive potential, i.e. the formation of several generations during a single growing season (Temperli et al. 2015). Most importantly, bark beetle outbreaks and the associated decline in spruce stands occurred mainly in the lowland areas of Slovenia, where spruce does not grow naturally, which is consistent with our results of the decline in the growing stock of spruce according to the data from 2010 to 2018 . In total, the most severely damaged forest compartments with the largest decrease in spruce growing stock were located at altitudes below 500 m. In these low-altitude forests, forest managers, private owners and even foresters forced the introduction of Norway spruce, largely ignoring the important criteria of (un) suitable local site conditions. Norway spruce is a typical example of how economically valuable tree species were largely favoured and planted beyond their natural ecological niche but are now under severe pressure (Vitasse et al. 2019). However, monospecific spruce stands in unsuitable locations, such as steep, south facing slopes with shallow soils, can also be exposed to spruce decline even at higher altitudes. Such monospecific spruce stands are particularly susceptible to disturbances such as storms (windthrows), drought and insect outbreaks (Lindner et al. 2010). Therefore, management systems that promote forest diversity significantly reduce the degree of disturbance (Dobor et al. 2020). Forest structure and composition, which are associated with management measures such as the promotion of coniferous trees and an increase in timber volume as well as the lack of appropriate silvicultural measures in the younger developmental phases, are highly susceptible to disturbances in forest stands (Seidl et al. 2011b).

At the European level and in Slovenia, European beech and Norway spruce are the two most important tree species in temperate and boreal forests. It is predicted that these species will lose large parts of their potential distribution range and be replaced by species with a more thermophilic character (Hanewinkel et al. 2013). Recently, however, it has been shown that CC in Austria even favours European beech and oak species (Thom et al. 2017), and the proportion of beech has also increased in Slovenia. In the long term, beech forests are likely to be threatened (Kutnar \& Kobler 2011, 2014, Hanewinkel et al. 2013). The physiological performance, growth and competitiveness of beech can be impaired by such altered (micro)climatic conditions (Peuke et al. 2002, Geßler et al. 2007, Stojanović et al. 2013).

\section{Changes in forest stands}

Slovenia lies in the transition zone where different geographical regions meet (e.g. Mediterranean, Alps and Dinaric Mountains, Pannonian Basin). Therefore, different natural conditions have the potential to experience different types of disturbances and natural hazards. Apart from episodic disturbance events, the most serious threat to Slovenian forests could lie in the vicinity of the Mediterranean, where $\mathrm{CC}$ is expected to increase the negative effects of adverse climatic conditions (e.g. summer droughts, heat-induced stress, forest fires) on forest growth and health (Pereira et al. 2005, Moriondo et al. 2006).

Spatial modelling of the future distribution of tree species forest types based on different climate scenarios for Slovenia shows a significant potential reduction in mesic forest types, in which European beech, silver fir and Norway spruce are the dominant tree species in the overstory layer. These forest types and tree species are known for their vulnerability to extreme climatic events such as high mean summer temperatures and drought stress. The future success of these species is endangered in the context of $\mathrm{CC}$, while other forest types and tree species (with lower forest economic value and higher fire risk), e.g. thermophilus broadleaves and drought-tolerant forests, are likely to extend their distribution range in 
Slovenia (Kutnar \& Kobler 2011) and Europe (Hanewinkel et al. 2013).

In the context of forest disturbance effects, cascade or domino effects are of particular importance when there are multiple interactions between abiotic and biotic disturbance factors (Kausrud et al. 2012, Seidl et al. 2017, de Groot et al. 2018). In forests where the decline in net primary production is extreme or persists over several growing seasons, increased susceptibility to insects or diseases is possible. The dominant tree species studied in this research (Norway spruce, European beech, European silver fir) are relatively unspecific with respect to soil and terrain conditions (Zupančič 1999, Dakskobler 2008); therefore, their distribution is mainly determined by climatic constraints (Falk \& Hempelmann 2013). CC will favour forests with tree species that are not predominant under current environmental conditions.

Disturbances and CC will not only change the distribution of tree species and forests, but they will also change understory vegetation (Stevens et al. 2015, Kutnar et al. 2019) and interrupt the sustainable provision of forest ecosystem services (Thom \& Seidl 2016), as well as result in the loss of economic value (Hanewinkel et al. 2013). For example, Dinaric fir-beech forest, which is one of the most extensive forest types in Slovenia (Dakskobler 2008), has also been one of the most severely damaged forests in this area in recent years. These forests are important for their role in timber production and for providing many other ecosystem services. Due to their location in limestone karst areas, their ecological and biodiversity aspects are of great importance. These forests are the habitat of many species of European interest (Habitat Directive, 1992), and a large part of them has been designated as part of the Natura 2000 network (Skoberne 2004, Kutnar et al. 2011). The significant alteration or even loss of Dinaric fir-beech forests may lead to the loss of species habitats and the potential extinction of many key forest species in this area. Since many forestdwelling species are highly dependent on the predominant tree species, a delayed response to a changing climate may contribute to an extinction debt and climate-induced loss of biodiversity (Thom et al. 2017). CC has already caused numerous shifts in species abundance and distribution (Parmesan \& Yohe 2003) and will be a major driver of species extinction in the near future (Thomas et al. 2004).

\section{Future perspective of forest management in view of $\mathrm{CC}$ and disturbances}

Possible increases in tree mortality associated with rising temperatures, climate-induced physiological stress and interactions with other climate-induced processes such as insect outbreaks are of particular concern for the future (Allen et al. 2010). The management systems aimed at maintaining the dominance of Norway spruce in the forest fail in the context of $\mathrm{CC}$, and none of the measures applied have been able to mitigate the effects of disturbances (Dobor et al. 2020).

The persistence of local and regional tree populations, for which the role of phenotypic variation may be an important factor, will be challenged due to warmer and drier climate conditions (Chmura et al. 2011). Bouchard et al. (2019) emphasized that the persistence of tree species is the key factor in forest changes. However, the response of tree populations exposed to unusually warm and dry conditions is still relatively poorly known for most species.

Since sustainable close-to-nature forest management is based on the imitation of less intensive disturbances, little attention has been paid to restoring more severe disturbance areas within forest landscapes (Diaci et al. 2017). However, research on adaptation to $\mathrm{CC}$ and disturbances has become increasingly important over the last two decades. Disturbances promote the reorganization of ecosystems since the increasing frequency and severity of disturbances are likely to accelerate 
the adaptation of forest ecosystems to $\mathrm{CC}$, but the increasing size of disturbances may have the opposite effect on forests (Thom et al. 2017). Forest conversion with warm-adapted tree species goes hand in hand with a loss of total growth performance compared to the current species composition. The question of which tree species should be promoted in view of $\mathrm{CC}$ and increasing harmful disturbances is an ongoing debate in forest ecology and management (Thurm et al. 2018). Foresters from many countries are looking for tree species or provenances able to cope with expected CC. Forest managers need to know to what extent and on which sites the tree species predominant in our study area, such as European beech, Norway spruce, and silver fir, can sustain viable populations in the coming decades and in which cases they should consider or promote alternative species (Vitasse et al. 2019, Thurm et al. 2018).

\section{Conclusions}

We discussed current changes in temperate forests in Slovenia (in the transition zone between Central Europe to SE Europe) caused by global warming and various disturbance factors in relation to climate change $(\mathrm{CC})$ predictions, and the main findings are as follows:

- $\mathrm{CC}$ and disturbances cause major alterations in the forest structure and species composition of temperate forests.

- The climate in the investigated region has warmed by about $0.4^{\circ} \mathrm{C}$ per decade.

- Various disturbance factors, which currently damage more than $1 \%$ of the total growing stock per year, are accelerating the changes in forests.

- After the severe ice storm in 2014 and associated bark beetle outbreaks and windthrows in the following years, salvage logging increased from about one third to two thirds of the total annual logging.

- Spruce has recently declined significantly in Slovenian forests, especially in low-elevation areas where it has been planted outside its natural range and where the climate has become unsuitable for spruce.

The results of our study complement existing knowledge on possible CC impacts on tree species and forest stands and contribute to the general understanding of forest dynamics in a time of rapid global environmental changes. On a shorter timescale, changes induced by disturbance factors represent stronger drivers of forest dynamics than the direct effect of CC. As there are no severe stand-replacing disturbances where a natural succession of ageing forest stands occurs, the effects of $\mathrm{CC}$ are expected to be experienced much more slowly. However, large-scale forest disturbances are able to accelerate the effects of $\mathrm{CC}$. The restoration of forest stands after intensive natural disturbances is becoming more frequent and more difficult under global changes. One of the future challenges will be to integrate multiple disturbance processes into forest management models, and for these purposes, understanding the forest dynamics affected by $\mathrm{CC}$ and disturbances will be essential.

\section{Acknowledgment}

This research study was supported by Research Program P4-0107, funded by the Slovenian Research Agency (ARRS) and by Public Forest Service (Task 1), funded by the Ministry of Agriculture, Forestry and Food of the Republic of Slovenia. We would like to thank many colleagues of the Slovenian Environment Agency (ARSO) for providing meteorological data and the Slovenia Forest Service (ZGS) for various data on forest stands and compartments. We are also grateful to two anonymous referees for providing helpful comments and suggestions on an earlier version of the manuscript. We thank Philip J. Nagel for proofreading and language editing.

\section{References}

Allen C.D., Macalady A.K., Chenchouni H., Bachelet D., McDowell N., et al., 2010. A global overview of drought and heat-induced tree 
mortality reveals emerging climate change risks for forests. For. Ecol. Manage. 259: 660-684. https://doi.org/10.1016/j.foreco.2019.117691

Anić I., Vukelić J., Mikac S., Bakšić D., Ugarković D., 2009. Utjecaj globalnih klimatskih promjena na ekološku nišu obične jele (Abies alba Mill.) u Hrvatskoj. [Effects of global climate change on the ecological niche of silver fir (Abies alba Mill.) in Croatia]. Šumarski list 133(3-4): 135144. https://hrcak.srce.hr/36397

ARSO, 2019. Archive of measurements observed and measured meteorological data in Slovenia. Agencija Republike Slovenije za okolje [Slovenian Environment Agency]. http:// meteo.arso.gov.si/met/sl/archive/ (accessed November 2019)

Attiwill P.M., 1994. The disturbance of forest ecosystems: the ecological basis for conservation management. For. Ecol. Manag. 63: 247-300. https://doi.org/10.1016/0378-1127(94)90114-7

Bengtsson J., Nilsson S.G., Franc A., Menozzi P., 2000. Biodiversity, disturbances, ecosystem function and management of European forests. For. Ecol. Manag. 132: 39-50. https://doi. org/10.1016/S0378-1127(00)00378-9

Blennow K., Andersson M., Sallnäs O., Olofsson E., 2010. Climate change and the probability of wind damage in two Swedish forests. For. Ecol. Manage. 259: 818-830. https://doi. org/10.1016/j.foreco.2009.07.004

Boisvert-Marsh L., Périé C., de Blois S., 2014. Shifting with climate? Evidence for recent changes in tree species distribution at high latitudes. Ecosphere 5(7): 83. https:/doi. org/10.1890/ES14-00111.1

Bouchard M., Aquilué N., Périe C., Lambert M.-C., 2019. Tree species persistence under warming conditions: A key driver of forest response to climate change. For. Ecol. Manage. 442: 96-104. https://doi.org/10.1016/j. foreco.2019.03.040

Box E.O., Crumpacker D.W., Hardin E.D., 1999. Predicted effects of climatic change on distribution of ecologically important native tree and shrub species in Florida. Clim. Chang. 41: 213-248. https://doi.
org/10.1023/A:1005483507351

Brice M.-H., Cazelles K., Legendre P., Fortin M.J., 2019. Disturbances amplify tree community responses to climate change in the temperateboreal ecotone. Glob. Ecol. Biogeogr. 28: 16681681. https://doi.org/10.1111/geb.12971

Broadmeadow M.S.J., Ray D., Samuel C.J.A., 2005. Climate change and the future for broadleaved tree species in Britain. Forestry 78: 145-161. https://doi.org/10.1093/forestry/cpi014 Brook B., Sodhi N., Bradshaw C., 2008. Synergies among extinction drivers under global change. Trends Ecol. Evol. 23: 453-460. https://doi. org/10.1016/j.tree.2008.03.011.

Čarni A., Marinček L., Seliškar A., Zupančič M., 2002. Vegetacijska karta gozdnih združb Slovenije, 1:400.000 [The Vegetation Map of Forest Communities of Slovenia, 1:400.000]. ZRC SAZU, Biološki inštitut Jovana Hadžija, Ljubljana.

Chmura D.J., Anderson P.D., Howe G.T., Harrington C.A., Halofsky J.E., Peterson D.L., Shaw D.C., St.Clair J.B., 2011. Forest responses to climate change in the northwestern United States: Ecophysiological foundations for adaptive management. For. Ecol. Manage. 261: 1121-1142. https://doi.org/10.1016/j. foreco.2010.12.040

Dakskobler I., 2008. A review of beech sites in Slovenia. Zbornik Gozdarstva in Lesarstva, 87: 3-14. http://www.dlib.si/details/ URN:NBN:SI:doc-43YP658B

Danneyrolles V., Dupuis S., Fortin G., Leroyer M., de Römer A., et al., 2019. Stronger influence of anthropogenic disturbance than climate change on century-scale compositional changes in northern forests. Nat. Commun. 10: 1265. https://doi.org/10.1038/s41467-019-09265-z

de Groot M., 2014. Trendi in napovedi gostote populacij smrekovih podlubnikov po žledolomu 2014 v Sloveniji: stanje pomlad 2014. Napovedi o zdravju gozdov. https://oi.org/10.20315/ NZG.20

de Groot M., Kolšek M., Kavčič A., 2016. Napoved ulova smrekovih lubadarjev (Ips typographus in Pityogenes chalcographus) v 
kontrolne feromonske pasti tipa Theysohn za leto 2016. Napovedi o zdravju gozdov. https:// doi.org/10.20315/NZG.26

de Groot M., Ogris N., Kobler A., 2018. The effects of a large-scale ice storm event on the drivers of bark beetle outbreaks and associated management practices. For. Ecol. Manage. 408: 195-201. https://doi.org/10.1016/j. foreco.2017.10.035

de Mandiburu F., 2020. Package "agricolae". Statistical Procedures for Agricultural Research, version 1.3-3. Available at CRAN repository. https://cran.r-project.org/web/packages/ agricolae/index.html

Diaci J., 2006. Nature-based silviculture in Slovenia: origins, development and future trends. In: Diaci J. (Ed.), Nature-based Forestry in Central Europe. Alternatives to Industrial Forestry and Strict preservation. Studia Forestalia Slovenica, Ljubljana, pp. 119-132.

Diaci J., Roženbergar D., Fidej G., Nagel T.A., 2017. Challenges for uneven-aged silviculture in restoration of post-disturbance forests in Central Europe: A synthesis. Forests 8: 378. https://doi.org/10.3390/f8100378

Dobor L., Hlásny T., Zimová S., 2020. Contrasting vulnerability of monospecific and species-diverse forests to wind and bark beetle disturbance: The role of management. Ecol. Evol. 10.: 12233-12245. https:/doi. org/10.1002/ece3.6854

ESRI, 2018. ArcGIS 10.6 Geographic Information Systems (GIS) software package. Environmental Systems Research Institute.

EUROSTAT, 2018. GISC0: Geographical information and maps - Countries 2016, Eurostat.

Falk W., Hempelmann N., 2013. Species favourability shift in Europe due to climate change: A case study for Fagus sylvatica L. and Picea abies (L.) Karst. based on an ensemble of climate models. J. Climatol. 18 p. https://doi. org/10.1155/2013/787250

Ficko A., Poljanec A., Boncina A., 2011. Do changes in spatial distribution, structure and abundance of silver fir (Abies alba Mill.) indicate its decline? For. Ecol. Manage. 261: 844-854. https://doi.org/10.1016/j.foreco.2010.12.014

Geßler A., Keitel C., Kreuzwieser J., Matyssek R., Seiler W., Rennenberg H., 2007. Potential risks for European beech (Fagus sylvatica L.) in a changing climate. Trees 21(1): 1-11. https://doi. org/10.1007/s00468-006-0107-x

Goldammer J.G., Shukhinin A., Csiszar I., 2005. The current fire situation in the Russian Federation: implications for enhancing international and regional cooperation in the UN framework and the global programs on fire monitoring and assessment. Int. Forest Fire News 32: 13-42.

Goldblum D., Rigg L.S., 2010. The deciduous forest - boreal forest ecotone. Geogr. Compass 4: 701-717. https://doi.org/10.1111/j.17498198.2010.00342.X

Good P., Barring L., Giannakopoulos C., Holt T., Palutikof J.P., 2006. Nonlinear regional relationships between climate extremes and annual mean temperatures in model projections for 1961-2099 over Europe. Clim. Res. 13: 1934. https://doi.org/10.3354/cr031019

Grecs Z., Kolšek M., 2017. Natural disasters are increasingly affecting forest management. Gozdarski vestnik 74: 185-202 https:// www.dlib.si/stream/URN:NBN:SI:docGJ3IQ0UK/70df1336-a113-4d71-acf570a5d5bdff1c/PDF [in Slovenian].

Habitat Directive, 1992. Council Directive 92/43/ EEC of 21 May 1992 on the conservation of natural habitats and of wild fauna and flora. http://eur-lex.europa.eu/LexUriServ/ LexUriServ.do?uri=CELEX:31992L0043: EN:HTML

Hanewinkel M., Cullmann D.A., Schelhaas M.J., Nabuurs G.-J., Zimmermann N.E., 2013. Climate change may cause severe loss in the economic value of European forest land. Nat. Clim. Chang. 3: 203-207. https://doi. org/10.1038/nclimate1687

Hijmans R.J., Graham C.H., 2006. The ability of climate envelope models to predict the effect of climate change on species distributions. Glob. Chang. Biol. 12: 2272-2281. https://doi. 
org/10.1111/j.1365-2486.2006.01256.x

IPCC, 2001. Climate Change 2001: impacts, adaptation and vulnerability. In: McCarthy J.J., Canziani O.F., Leary N.A., Dokken D.J., White K.S. (eds.), Contribution of Working Group II to the Third Assessment Report of the Intergovernmental Panel on Climate Change (IPCC). Cambridge University Press, Cambridge, UK

IPCC,2007.ClimateChange2007:impacts, adaptation and vulnerability. In: Parry M.L., Canziani O.F., Palutikof J.P., van der Linden P.J., Hanson C.E. (eds.), Contribution of Working Group II to the Fourth Assessment Report of the Intergovernmental Panel on Climate Change, Cambridge University Press, Cambridge, UK, $976 \mathrm{p}$.

IPCC, 2014. Climate Change 2014: Synthesis Report. Contribution of Working Groups I, II and III to the Fifth Assessment Report of the Intergovernmental Panel on Climate Change. Core Writing Team: Pachauri R.K., Meyer L.A. (eds.). IPCC, Geneva, Switzerland, 151 p.

Kausrud K., Økland B., Skarpaas O., Gregoire J.C., Erbilgin N., Stenseth N.C., 2012. Population dynamics in changing environments: the case of an eruptive forest pest species. Biol. Rev. 87: 34-51. https://doi.org/10.1111/j.1469185X.2011.00183.x

Kellomäki S., Leinonen S. (eds.) 2005. Management of European forests under changing climatic conditions. Final report of the project Silvistrat. University of Joensuu, Research Notes 163, Joensuu, Finland, 427 p.

Koca D., Smith S., Sykes M.T., 2006. Modelling regional climate change effects on potential natural ecosystems in Sweden. Clim. Chang. 78: 381-406. https://doi.org/10.1007/s10584005-9030-1

Kutnar L., Kobler A., 2011. Prediction of forest vegetation shift due to different climate-change scenarios in Slovenia. Šumarski list, 135: 113126. https://hrcak.srce.hr/67619

Kutnar L., Kobler A., 2014. Possible impacts of global warming on forest tree species composition in Slovenia. In: Zlatic M., Kostadinov S. (Ed.) Challenges; Sustainable
Land Management - Climate Changes. Adavances in GeoEcology, 43, Catena Verlag, pp. 221-230.

Kutnar L., KoblerA., 2013. The current distribution of black locust (Robinia pseudoacacia L.) in Slovenia and predictions for the future. Acta Silvae et Ligni 102 : 21-30 [in Slovenian]. http:// eprints.gozdis.si/121/1/Acta_102-2-LK.pdf

Kutnar L., Matijašić D., Pisek R., 2011. Conservation status and potential threats to Natura 2000 forest habitats in Slovenia. Šumarski list 135: 215-230. http://hrcak.srce. $\mathrm{hr} / 71628$

Kutnar L., Nagel T. A., Kermavnar J., 2019. Effects of disturbance on understory vegetation across Slovenian forest ecosystems. Forests 10: 1048, https://doi.org/10.3390/f10111048

Lasch P., Linder M., Erhard M., Suckow F., Wenzel A., 2002. Regional impact assessment on forest structure and functions under climate change-the Brandenburg case study. For. Ecol. Manage. 162: 73-86. https://doi.org/10.1016/ S0378-1127(02)00051-8

Lexer M.J., Honninger K., Scheifinger H., Matulla C., Groll N., et al., 2002. The sensitivity of Austrian forests to scenarios of climatic change: a large-scale risk assessment based on a modified gap model and forest inventory data. For. Ecol. Manage. 162: 53-72. https://doi. org/10.1016/S0378-1127(02)00050-6

Lindner M., Maroschek M., Netherer S., Kremer A., Barbati A., et al., 2010. Climate change impacts, adaptive capacity, and vulnerability of European forest ecosystems. For. Ecol. Manage. 259: 698-709. https://doi.org/10.1016/j. foreco.2009.09.023

Maracchi G., Sirotenko O., Bindi M., 2005. Impacts of present and future climate variability on agriculture and forestry in the temperate regions: Europe. Clim. Chang. 70: 117-135. https://doi.org/10.1007/1-4020-4166-7_6

Martínez-Vilalta J., Pińol J., 2002. Drought induced mortality and hydraulic architecture in pine populations of the NE Iberian Peninsula. For. Ecol. Manage. 161: 247-256. https://doi. org/10.1016/S0378-1127(01)00495-9 
Moriondo M., Good P., Durao R., Bindi M., Gianakopoulos C., Corte-Real J., 2006. Potential impact of climate change on fire risk in the Mediterranean area. Clim. Res. 31: 85-95. https://doi.org/10.3354/cr031085

Nagel T.A., Firm D., Rozenbergar D., Kobal M., 2016. Patterns and drivers of ice storm damage in temperate forests of Central Europe. Eur. J. Forest. Res. 135: 519-530. https://doi. org/10.1007/s10342-016-0950-2

Nagel T.A., Mikac S., Dolinar M., Klopcic M., Keren S., Svoboda M., Diaci J., Boncina A., Paulic V., 2017. The natural disturbance regime in forests of the Dinaric Mountains: A synthesis of evidence. For. Ecol. Manage. 388: 29-42. https://doi.org/10.1016/j.foreco.2016.07.047

Ogris N., Grecs Z., 2016. Prenamnožitev osmerozobega in šesterozobega smrekovega lubadarja v Sloveniji v 2016. Napovedi o zdravju gozdov. https://doi.org/10.20315/ NZG.27

Parmesan C., Yohe G.A., 2003. A globally coherent fingerprint of climate change impacts across natural systems. Nature 421: 37-42. https://doi.org/10.1038/nature01286

Pearson R.G., Dawson T.P., 2003. Predicting the impacts of climate change on the distribution of species: are bioclimate envelope models useful? Glob. Ecol. Biogeogr. 12(5): 361-371. https:// doi.org/10.1046/j.1466-822X.2003.00042.X

Pereira M.G, Trigo R.M., da Camara C.C., Pereira J.M.C., Leite S.M., 2005. Synoptic patterns associated with large summer forest fires in Portugal. Agric. For. Meteorol. 129: 11-25. https://doi.org/10.1016/j.agrformet.2004.12.007 Peuke A.D., Schraml C., Hartung W., Rennenberg H., 2002. Identification of drought-sensitive beech ecotypes by physiological parameters. New Phytol. 154: 373-387. https:/doi. org/10.1046/j.1469-8137.2002.00400.x

Polemio M., Casarano D., 2004. Rainfall and drought in Southern Italy (1821-2001). UNESCO/IAHS/IWHA, 286 p.

Pretzsch H., Durský J., 2002. Growth reaction of Norway spruce (Picea abies (L.) Karst.) and European beech (Fagus sylvatica L) to possible climatic changes in Germany. A sensitivity study. Forstwiss. Cent.bl. 121(S1): 145-154.

Runkle J.R., 1985. Disturbance regimes in temperate forests. In: Pickett S.T.A., White P.S. (eds.), The ecology of natural disturbance and patch dynamics. Academic Press. pp. 17-33.

$\mathrm{R}$ Core Team, 2018. R: A language and environment for statistical computing. R Foundation for Statistical Computing, Vienna, Austria. URL https://www.R-project.org/.

Schelhaas M.J., Nabuurs G.J., Schuck A., 2003. Natural disturbances in the European forests in the 19th and 20th centuries. Glob. Chang. Biol. 9: 1620-1633. https://doi.org/10.1046/j.13652486.2003.00684.x

Seidl R, Fernandes P.M., Fonseca T.F., et al., 2011a. Modelling natural disturbances in forest ecosystems: a review. Ecol. Model. 222: 903-924. https://doi.org/10.1016/j. ecolmodel.2010.09.040

Seidl R., Schelhaas M.-J., Lexer M.J. 2011 b. Unraveling the drivers of intensifying forest disturbance regimes in Europe. Glob. Chang. Biol. 17: 2842-2852. https://doi.org/10.1111/ j.1365-2486.2011.02452.x

Seidl R., Schelhaas M.-J., Rammer W., Verkerk P.J., 2014. Increasing forest disturbances in Europe and their impact on carbon storage. Nat. Clim. Chang. 4: 806-810. https://doi. org/10.1038/nclimate2318

Seidl R., Thom D., Kautz M., Martin-Benito D., Peltoniemi M., et al., 2017. Forest disturbances under climate change. Nat. Clim. Chang. 7: 395-402. https://doi.org/10.1038/nclimate3303

Skoberne P., 2004. Strokovni predlog za omrežje Natura 2000 [Expertise proposal for Natura 2000 network]. Proteus 66: 400-406.

Stevens J.T., Safford H.D., Harrison S., Latimer A.M., 2015. Forest disturbance accelerates thermophilization of understory plant communities. J. Ecol. 103: 1253-1263. https:// doi.org/10.1111/1365-2745.12426

Stojanović D., Kržić A., Matović B., Orlović S., Duputie A., Djurdjević V., Galić Z., Stojnić S., 2013. Prediction of the European beech (Fagus sylvatica L.) xeric limit using a regional climate 
model: An example from southeast Europe. Agric. For. Meteorol. 176: 94-103. https://doi. org/10.1016/j.agrformet.2013.03.009

Stojanović D.B, Matović B., Orlović S., Kržič A., Trudić B., Galić Z., Stojnić S., Pekeč S., 2014. Future of the main important forest tree species in Serbia from the climate change perspective. South-east European Forestry 5(2): 117-124. http://dx.doi.org/10.15177/seefor.14-16

Taccoen A., Piedallu C., Seynave I., Perez V., Gégout-Petit A., et al., 2019. Background mortality drivers of European tree species: climate change matters. Proc. R. Soc. B 286: 20190386. https://doi.org/10.1098/ rspb.2019.0386

Temperli C., Veblen T.T., Hart S.J., Kulakowski D., Tepley A.J., 2015. Interactions among spruce beetle disturbance, climate change and forest dynamics captured by a forest landscape model. Ecosphere 6(11): 231, 20 p. https://doi. org/10.1890/ES15-00394.1

ThomD., SeidlR., SteyrerG., KrehanH., Formayer H., 2013. Slow and fast drivers of the natural disturbance regime in Central European forest ecosystems. For. Ecol. Manage. 307: 293-302. https://doi.org/10.1016/j.foreco.2013.07.017

Thom D., Seidl T., 2016. Natural disturbance impacts on ecosystem services and biodiversity in temperate and boreal forests. Biol. Rev. 91: 760-781. https://doi.org/10.1111/brv.12193

Thom D., Rammer W., Seidl R., 2017. Disturbances catalyze the adaptation of forest ecosystems to changing climate conditions. Glob. Chang. Biol. 23: 269-282. https://doi. org/10.1111/gcb.13506

Thom D., Sommerfeld A., Sebald J., Hagge J., Müller J., Seidl R., 2020. Effects of disturbance patterns and deadwood on the microclimate in European beech forests. Agric. For. Meteorol. 291: $\quad 108066$. https://doi.org/10.1016/j. agrformet.2020.108066

Thomas C.D., Cameron A., Green R.E., Bakkenes M., Beaumont L.J., et al., 2004. Extinction risk from climate change. Nature 427: 145-148. https://doi.org/10.1038/nature02121

Thurm E.A., Hernandez L., Baltensweiler A.,
Ayan S., Rasztovits E., et al., 2018. Alternative tree species under climate warming in managed European forests. For. Ecol. Manage. 430: 485-497. https://doi.org/10.1016/j. foreco.2018.08.028

Vanderwel M.C., Purves D.W., 2014. How do disturbances and environmental heterogeneity affect the pace of forest distribution shifts under climate change? Ecography 37: 10-20. https:// doi.org/10.1111/j.1600-0587.2013.00345.x

Vitasse Y., Bottero A., Rebetez M., Conedera M., Augustin S., Brang P., Tinner W., 2019. What is the potential of silver fir to thrive under warmer and drier climate? Eur. J. For. Res. 138: 547-560. https://doi.org/10.1007/s10342-019-01192-4

White P.S., Pickett S.T.A., 1985. Natural disturbance and patch dynamics: An introduction. In: Pickett S.T.A., White P.S. (Eds.), The ecology of natural disturbance and patch dynamics. Academic Press. pp. 3-13.

ZGS, 2005-2019. Poročila Zavoda za gozdove Slovenije o gozdovih za leta od 2004 do 2018 [Annual Reports of Slovenia Forest Service for year 2004 to year 2018].

ZGS, 2010a. Forest stands data. Zavod za gozdove Slovenije [Slovenia Forest Service].

ZGS, 2010b. Forest compartments data. Zavod za gozdove Slovenije [Slovenia Forest Service].

ZGS, 2015. Forest compartments data. Zavod za gozdove Slovenije [Slovenia Forest Service].

ZGS, 2018a. Forest stands data. Zavod za gozdove Slovenije [Slovenia Forest Service].

ZGS, 2018b. Forest compartments data. Zavod za gozdove Slovenije [Slovenia Forest Service].

Zohner C.M., Benito B.M., Svenning J.C., Renner S.S., 2016. Day length unlikely to constrain climate-driven shifts in leaf-out times of northern woody plants. Nature Climate Change 6(12): 1120-1123. https://doi.org/10.1038/ nclimate3138

Zupančič M., 1999. Smrekovi gozdovi v Sloveniji (Spruce forests in Slovenia). Dela Razreda za naravoslovne vede, vol. 36, Slovenska akademija znanosti in umetnosti, Ljubljana, 222 p. 